\title{
Attitudes toward genetically modified organisms in Poland: to GMO or not to GMO?
}

\author{
Piotr Rzymski $^{1}$ • Aleksandra Królczyk ${ }^{1}$
}

Received: 13 September 2015 / Accepted: 5 April 2016/Published online: 5 May 2016

(C) The Author(s) 2016. This article is published with open access at Springerlink.com

\begin{abstract}
Genetically modified organisms (GMOs) are a subject of on-going scientific, political and social discussions in Member States of the European Union (EU) concerning their use, benefits, risks, safety and limitations. EU societies have every right to substantive information and education in biotechnology, yet they appear to be misinformed by contradictory views and sensationalism. The present study investigated the level of knowledge and the attitude of citizens of Poland $(n=1021)$ towards the various uses of GMOs. As found, the use of GMOs in medicine and pharmacy received slight approval from the surveyed group, and was generally perceived as the greatest benefit of GMOs. In contrast, most respondents were against the production and distribution of GM food products on the Polish market or at least favoured the labelling of any product that contains a GM component. The majority of individuals who were willing to accept GM foods also demanded their labelling. The studied group revealed various concerns related to the safety of GM foods, particularly their potential effect on health and the environment. Generally, the greatest scepticism towards GMOs and GM foods was expressed by farmers, medical workers and school teachers while the greatest enthusiasm was shown by students of medical and life sciences, and researchers/academicians. Importantly, most of those taking part in the survey admitted that their knowledge of GMOs was insufficient, expressed a
\end{abstract}

Electronic supplementary material The online version of this article (doi:10.1007/s12571-016-0572-z) contains supplementary material, which is available to authorized users.

Piotr Rzymski

rzymskipiotr@ump.edu.pl

1 Department of Environmental Medicine, Poznan University of Medical Sciences, Poznań, Poland willingness to improve it, and expected school teachers, academicians and researchers to be actively involved in this process. In conclusion, the present study underlines the urgent need to implement evidence-based educational programmes so as to raise the public understanding of the current possibilities and limitations of GMO-based technology in Poland.

Keywords GM foods · GMO • Consumers' acceptance · Public opinion

\section{Introduction}

Due to improved laboratory techniques and tools for genome sequencing, the pharmaceutical, medical and agricultural use of genetically modified organisms (GMOs) is increasingly being investigated and developed on the market as a promising technology in drug manufacturing (Walsh 2005), highresolution diagnostics (Panteli et al. 2015), human therapies (Jefferson et al. 2015), disease prevention, environmental management (Marinotti et al. 2013; Alphey 2014), bioremediation processes (Rylott et al. 2015), and food production (Brookes and Barfoot 2015),

At the same time, GMOs and GM foods in particular raise continuous public debate as regards their safety, risks, legislation, labelling and restriction (Burke 2012; McHughen 2013). It is beyond any doubt that GMOs are one of the most controversial technologies to appear on the market in recent decades. Consumer attitudes towards them vary across cultures and geographical regions (Chen \& Li 2007). In Europe agrobiotechnology has long had a particularly bad press (Marris 2001) and its prospects have significantly worsened over the years (Papatryfon et al., 2008) although media coverage has recently become more balanced in some regions (Moses, 2012). 
A number of reasons have been suggested as potentially responsible for the reluctant and sceptical attitudes towards GMO-based technology, including a lack of public understanding of the science, difficulties in defining what GMOs are exactly, ethical or religious beliefs, and little or no perception of the benefits that GMOs can bring (Comstock 2002; Sturgis et al. 2005; Aerni 2013). The drastically contradictory views of pro and anti-GMO camps expressed in media debates have also helped to generate the general misinformation and confusion (Kuntz 2014). Moreover, deliberate anti-GM actions driven by nongovernmental organizations have been widely publicized in recent years and undoubtedly have added to a reluctance to accept GMOs from a significant part of the general public (Paarlberg 2014). This, in turn, has influenced political decisions, currently reflected by internal disagreement between Member States of the European Union (EU) and problems in reaching a common position towards GMOs, particularly GM crops (Lucht 2015). This also has had an effect on public sector research funding (Fedoroff 2015).

Considering that public opinion has a significant impact on the development and marketing of GMOs in Europe (Boccia and Sarnacchiaro 2015), it is essential to identify current attitudes toward this biotechnology in different countries in order to understand public fears and determine potential knowledge gaps. It is also important to recognize the expectations of the public related to genetic engineering, including legislation and sources that should play a primary role in facilitating the information. This can determine future decisions of the policymakers who have to respond to both public expectations and the biotechnological industries whose product success depends on stakeholders (e.g. farmers) and customers (consumers) decisions. In accordance with the Directive (EU) 2015/412 of the European Parliament and of the Council of 11 March 2015 amending Directive 2001/18/EC, Member States of EU can decide individually whether or not to implement the cultivation of GM crops. In this matter, Poland chose to request a full opt-out for their territory in late 2015. GM foods can still be imported and distributed in Poland but require mandatory labelling (Regulation (EC) 1829/2003). These products do not dominate the market and are mostly represented by vegetable oils derived from GM seeds (Twardowski 2008).

In an attempt to comprehensively investigate these issues, the present study evaluated current knowledge of GMOs among the Polish population, attitudes towards their use and their potential benefits, the general fears and expectations related to GM foods and views on their production and distribution as well as labelling policy. A number of earlier studies have assessed each of these issues in various other countries (Verdurme and Viaene 2003; Sturgis et al. 2005; Chen and Li 2007). The present study has evaluated all of them at once and has made a comparison of them among groups of different demographic characteristics. Such a simultaneous comparison is of great interest to those working in the biotechnological industry, policy makers and some members of the general public, allowing identification of those who are enthusiasts or opponents of GMO technology. Furthermore, the results of the study could also be useful in developing evidence-based educational programmes designed to raise public understanding of the possibilities and limitations, risks and benefits of biotechnology.

\section{Materials and methods}

\section{Participants and survey}

As previously indicated, knowledge and general attitudes are the core elements of the hypothetical model intentions related to GMOs and GM food (Verdurme and Viaene 2003). Therefore, the present study employed an anonymous, selfdesigned, structured questionnaire that concerned:

(i) general knowledge of GMOs - surveyed individuals explained the term "GMO", declared their level of knowledge, indicated main sources of information, claimed whether they were willing to improve their knowledge and if positive, indicated the main entities that should participate in this process.

(ii) attitude towards regulation of GM foods - surveyed individuals indicated whether GM foods could be produced and distributed in Poland, declared whether they expected GM foods to be labelled (and if yes, declared whether brief or detailed information were necessary) and evaluated whether, in their opinion, current regulations concerning GM foods in Poland were adequate or not.

(iii) attitude towards safety of GM foods - surveyed individuals indicated whether they perceived GM foods as safe for human health and the environment, specified their level of concern for particular threats using a five point scale and indicated the main potential reasons for antipathy towards GM foods.

(iv) attitude towards potential benefits of GMOs - surveyed individuals indicated what potential benefits (if any) may be acquired from GM food production and declared for what purposes (if any) they support the use of GMOs in general.

The demographic characteristics of each surveyed individual were also assessed and included: age, gender, education, place of living and profession. Within the latter five main groups were separated: 
(i) individuals who may potentially generate new information on GMOs and study this issue (biomedical genetics, researchers, biotechnologists);

(ii) individuals who may potentially educate the general public on GMO related issues (secondary school teachers and academicians);

(iii) individuals who may potentially become stakeholders (farmers and health professionals);

(iv) individuals who may potentially make decisions and shape general opinion on GMOs in the near future (secondary school pupils and students).

Considering that students of various disciplines may vary in their attitude, they were divided into three groups: i) students of life sciences; ii) students of medical sciences, and iii) students of other sciences.

A questionnaire was made available online for a period of one year (April, 2014 - April, 2015). In order to approach different professional groups, invitations to complete the questionnaire were sent to universities, secondary schools, farmers' associations and scientific societies, and were made available through social media and web portals.

\section{Statistical analyses}

The statistical analyses were performed using Statistica v.10.0 (StatSoft, Poland). Pearson's chi square test was used to compare the frequencies of the answers among the different groups. $P$ values of $<0.05$ were considered statistically significant.

\section{Results}

\section{Demographic characteristics}

The demographic characteristics of the polled group are presented in Table 1. A total of 1021 Polish citizens who completely answered the questionnaire were considered in this study. Most of the surveyed individuals were female, inhabited urban areas, and had completed their education at a tertiary level. Students, school pupils, teachers, medical workers, researchers and farmers were separated from the polled group for further comparisons (Table 1).

\section{Knowledge of GMOs}

Fewer than half of the studied individuals explained the term "GMO" correctly as "genetically modified organisms". A relatively high percentage of those surveyed related it exclusively to "genetically modified food". Over $20 \%$ were unable to provide any definition of this term (Table 2). Among other answers were responses such as "unnatural food", "food
Table 1 Demographical characteristics of Polish population enrolled in the study

\begin{tabular}{|c|c|}
\hline Characteristic & $n=1021$ \\
\hline \multicolumn{2}{|l|}{ Gender $n(\%)$} \\
\hline Female & $703(69)$ \\
\hline Male & $318(31)$ \\
\hline \multicolumn{2}{|l|}{ Age } \\
\hline Mean (years $\pm \mathrm{SD}$ ) & $32.1 \pm 14.3$ \\
\hline Median (range) years & $29(13-75)$ \\
\hline \multicolumn{2}{|l|}{ Place of living $n(\%)$} \\
\hline Urban $>200,000$ residents & $297(29.1)$ \\
\hline Urban $50,000-200,000$ residents & $351(34.4)$ \\
\hline Urban $<50,000$ residents & $215(21.1)$ \\
\hline Rural & $153(15.0)$ \\
\hline Not answered & $5(0.5)$ \\
\hline \multicolumn{2}{|l|}{ Education $n(\%)$} \\
\hline Primary & $168(16)$ \\
\hline Secondary & $324(32)$ \\
\hline Tertiary & $491(48)$ \\
\hline Vocational & $38(4)$ \\
\hline \multicolumn{2}{|l|}{ Profession $n(\%)$} \\
\hline Student (medical sciences) & $102(10.0)$ \\
\hline Student (life sciences) & $40(3.9)$ \\
\hline Student (other sciences) & $117(11.5)$ \\
\hline School pupils & $146(14.3)$ \\
\hline Medical worker & $54(5.3)$ \\
\hline Researcher/Academician & $57(5.6)$ \\
\hline School teacher & $118(11.6)$ \\
\hline Farmer & $40(3.9)$ \\
\hline Other & $347(34)$ \\
\hline
\end{tabular}

Table 2 Definition of "GMO" term given by the polled group and frequency of correct answer within individuals of different profession

\begin{tabular}{ll}
\hline & $\%$ \\
\hline "Genetically modified organism" & $45.2(n=462)$ \\
- Students (medical sciences) & 47.1 \\
- Students (life sciences) & 75.0 \\
- Students (other sciences) & 42.7 \\
- School pupils & 47.3 \\
- Medical workers & 51.9 \\
- Researchers & 63.2 \\
- Teachers/Academicians & 39.0 \\
- Farmers & 30.0 \\
- Other & 41.2 \\
"Genetically modified food" & $26.8(n=274)$ \\
"Genetically modified crops" & $1.5(n=15)$ \\
"I do not know" & $20.4(n=208)$ \\
Other definition & $6.1(n=62)$ \\
\hline
\end{tabular}


production company", "something dangerous inside the eggs" or "laboratory monsters". The correct definition was provided by individuals with a mean $( \pm S D)$ age of $30.7( \pm 12.8)$ years. It was given more frequently by citizens of urban areas $>200$, 000 residents $(54.2 \%)$ than smaller urban areas (50,000-20, 000 residents $-39.3 \% ;<50,000$ residents $-45.1 \%$; rural $43.1 \%)$, and more often by individuals with tertiary education $(51.2 \%)$ than those with vocational $(5.2 \%)$, secondary $(41.0 \%)$ and primary levels $(42.9 \%)$. Significant differences in this regard were also found among professional groups the correct answer was most often indicated by students of life sciences and researchers/academicians and least by farmers and school teachers (Tab. 2).

Most respondents $(53.1 \%)$ declared that they had insufficient knowledge of GMOs. The greatest frequency of such declarations was found among school teachers $(53.5 \%)$, medical students $(53.0 \%)$, students of other sciences than life and medical $(51.0 \%)$ and school pupils (48.3\%) with the lowest among researchers/academicians $(27.3 \%)$ and farmers $(28.2 \%)$. It was also significantly $(p<0.001)$ higher among citizens of smaller urban $(<50,000$ residents $-47.1 \% ; 50,000$ 200,000 residents $-50.2 \%$ ) and rural areas $(48.2 \%)$ than among individuals living in areas $>200,000$ residents $(37.5 \%)$.

Importantly, $78 \%$ of polled individuals expressed a willingness to improve their knowledge of GMOs. Internet, TV and the press were indicated as representing the main source of information on GMOs for the studied group. However, $79.9 \%$ admitted, in their opinion, issues related to GMOs were being insufficiently discussed in the media. Over half of the surveyed group $(61.5 \%)$ admitted that GMOs were a subject of political debate in Poland but its substantive level was mostly $(77.2 \%)$ rated as low. Over $40 \%$ of respondents indicated that they would like to gain more information on GMOs from academicians or school teachers, and scientific literature (Fig. 1).

\section{Attitude towards GM food regulation}

Most respondents $(60.2 \%)$ were decidedly against the production and distribution of GM foods in Poland while $21.0 \%$ had no opinion in this regard. Education had no effect on this attitude. The rural population was significantly more often opposed to GM foods $(67.6 \%)$ than populations of urban areas $(58.8 \%)$. The greatest unwillingness was revealed by medical workers, farmers and school teachers (Fig. 2).

The vast majority of the studied group (91.9\%) demanded that GM food products must be labelled, with $52.0 \%$ among them expecting detailed information to be printed on the product package. Nearly all opponents of production and distribution of GM foods in Poland (99.5 \%) anticipated labelling but also a high proportion of those approving these products demanded it $(83.5 \%)$. In the opinion of over half of the respondents $(57.8 \%)$ the current law regulating GMOs in

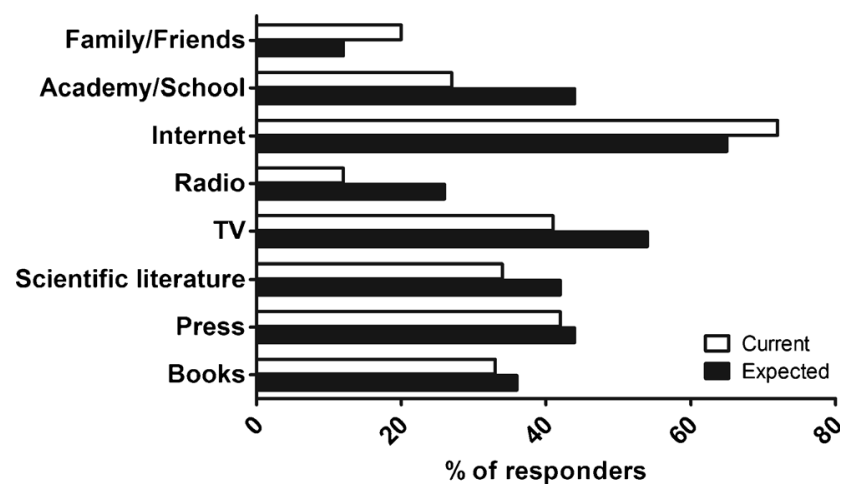

Fig. 1 Current and anticipated sources of information on GMOs in the surveyed group

Poland was not sufficient for consumer safety and should be improved while only $10.7 \%$ declared that it was adequate.

\section{Attitude towards safety of GM foods}

Generally the studied group viewed GM foods as unsafe for humans $(61.1 \%)$ and the environment $(64.7 \%)$. Place of living and education had no significant effect on these attitudes $(p>0.05)$. This reluctant attitude was, however, expressed with the greatest frequency by farmers (72.0 and $78.2 \%$, respectively), medical workers (78.8 and $77.0 \%$, respectively) and school teachers (68\% in both cases). Students of life and medical sciences (42.5 and $33.3 \%$, respectively), and researchers/academicians $(34.5 \%)$ were the most prevalent groups to consider them as safe. The vast majority of those polled admitted to being afraid of GM foods (82.2\%) and perceived them as less healthy than traditional ones $(67.7 \%)$. The greatest fears associated with GM foods included cancer development, allergy and threat to native biota (Table 3). For each concern considered in this study the

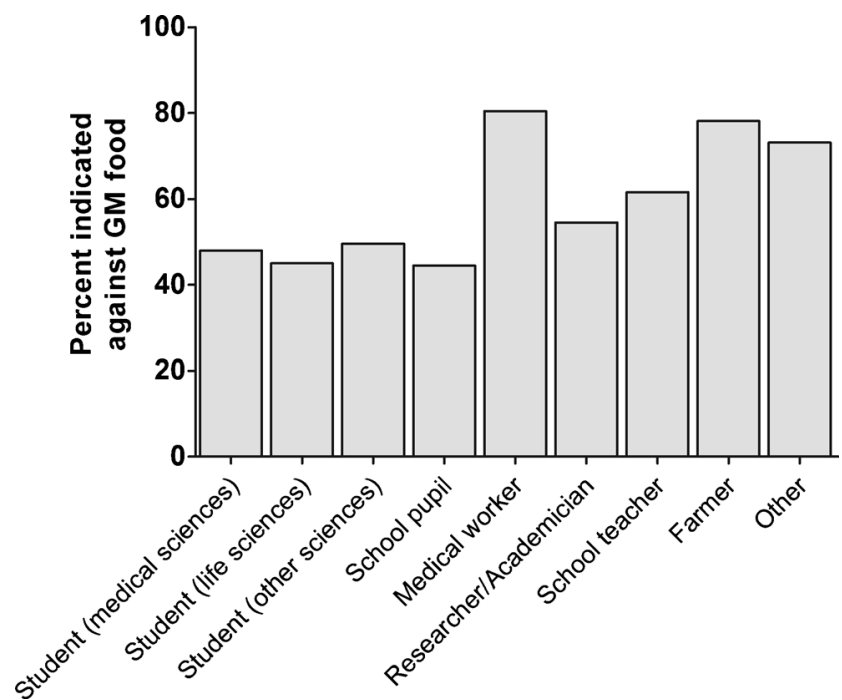

Fig. 2 Antipathy towards production and distribution of GM foods in Poland among various professional groups 
Table 3 Level of concern associated with GM foods among the studied group

\begin{tabular}{llllll}
\hline & Not afraid at all & $\begin{array}{l}\text { Slightly } \\
\text { afraid }\end{array}$ & Afraid & $\begin{array}{l}\text { Very } \\
\text { afraid }\end{array}$ & $\begin{array}{l}\text { My greatest } \\
\text { fear }\end{array}$ \\
\hline Cancer development & 11.9 & 10.7 & 11.6 & 13.9 & 51.9 \\
Reproductive harm & 16.9 & 14.0 & 18.9 & 14.8 & 35.3 \\
Allergy & 9.4 & 10.1 & 15.1 & 19.5 & 45.9 \\
Incorporation of exogenous DNA/genes & 29.0 & 13.4 & 12.2 & 12.4 & 32.9 \\
Gastrointestinal problem & 14.6 & 13.8 & 19.9 & 19.2 & 32.4 \\
Decrease of nutritional value & 20.0 & 14.4 & 16.7 & 14.0 & 34.8 \\
Deterioration of taste and appearance & 31.8 & 17.6 & 19.0 & 13.3 & 18.1 \\
Increase in food prices & 35.3 & 16.0 & 20.7 & 11.3 & 16.6 \\
Release of genes to environment & 13.3 & 14.0 & 16.9 & 14.9 & 40.6 \\
Threat to native biota & 6.9 & 8.3 & 13.2 & 16.4 & 55.2 \\
\hline
\end{tabular}

significantly increased frequency of "my greatest fear" answer indication was noted for individuals with vocational education and farmers. Urban and rural populations did not differ significantly in this regard.

The respondents defined the probable reasons behind antipathy towards GM foods. Most often answers included their potential threat to human health $(63.3 \%)$ and the environment $(54.1 \%)$, and a low level of knowledge with regard to genetic engineering $(57.0 \%)$. Other reasons included the effect of anti-GMO campaigns (33.1\%), religious and cultural boundaries $(15.0 \%)$ and lack of social progressiveness (14.2\%).

\section{Attitude towards GMO benefits}

The main identified benefits of GM food production by the surveyed group included elimination of hunger and a decrease of product prices although a relatively high proportion (one-third) did not perceive any benefits from their use (Fig. 3a). The greatest frequency of this last response was indicated by medical workers (57.7 \%) and farmers (56.2\%). Importantly, nearly $50 \%$ of those surveyed supported the medical use of GMOs in the production of drugs/vaccines or life-saving procedures. Over one third of studied individuals, however, did not support any use of GMOs (Fig. 3b) with medical workers and farmers being once again the most sceptical (57.7 and $46.9 \%$, respectively).

\section{Discussion}

Over the years, several studies have assessed public opinion and knowledge of GMOs in various regions of the world (Sturgis et al. 2005; Chen and Li 2007; Sorgo and Ambrožič-Dolinšek 2010; AbuQamar et al. 2015; Vecchione et al. 2015). According to the recent Eurobarometer survey, the worry level on GMOs in food
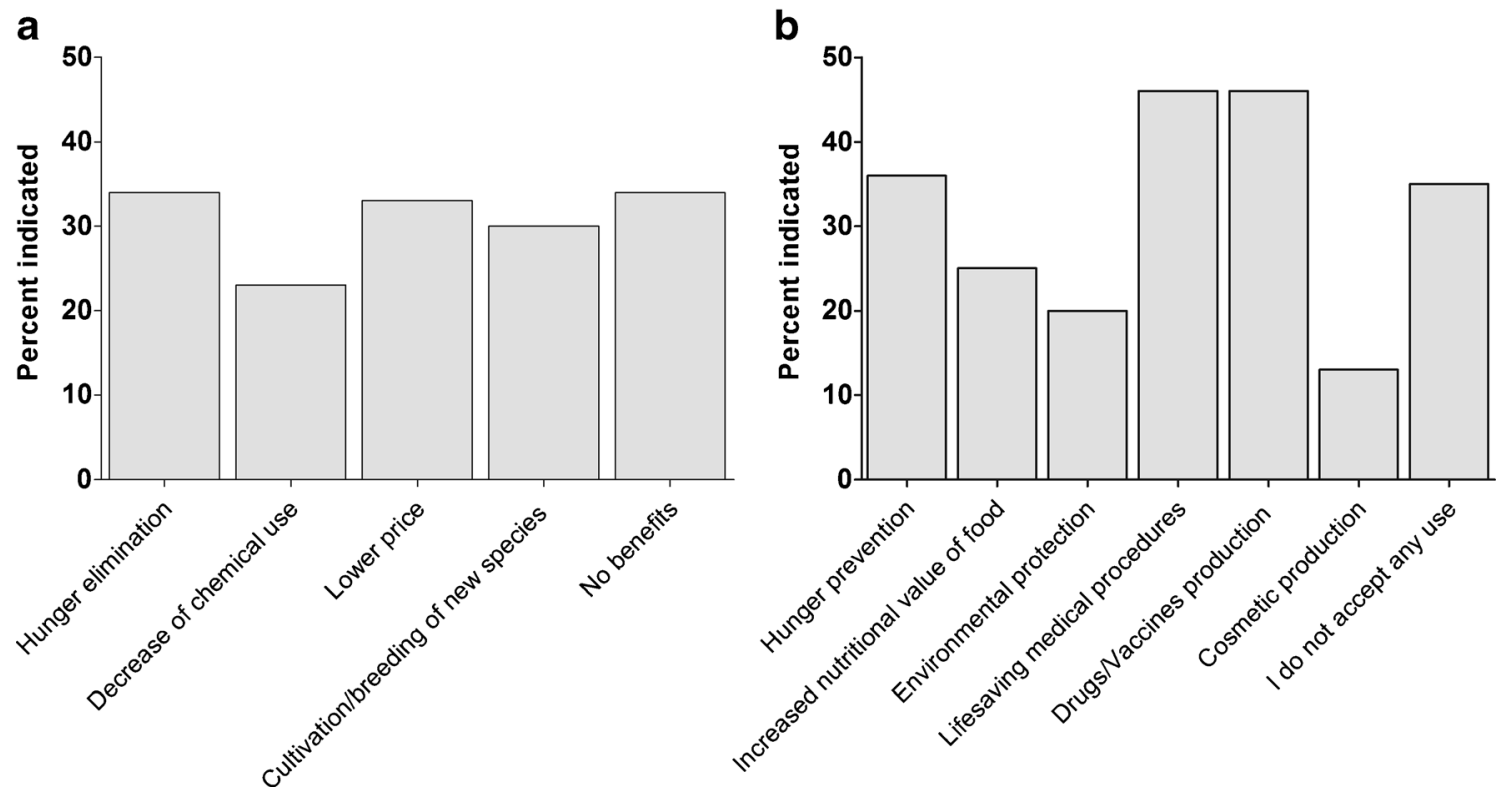

Fig. 3 Opinion of studied individuals on potential benefits of GM foods (a) and use of GMOs they are willing to accept (b) 
in the EU has generally increased since 2005 and varied from nearly $50 \%$ in Ireland up to over $80 \%$ in Lithuania and Greece, with a mean worry level of $66 \%$ for all Member States. In Poland it was as high as $77 \%$ with GMOs being perceived as a greater risk for respondents than microbial food contamination, allergic reactions to food and suffering from diet-related diseases (European Commission 2010; EFSA 2010). The present study, which compared attitudes in groups of different demographical characteristics, also highlighted a high degree of scepticism towards GMOs (and GM foods in particular) among Poles but there remained a need to further recognize exact public fears and expectations and potential reasons behind such a great frequency of reluctance to accept GMOs. The surveyed group of Poles may be undereducated as regards GMOs and expressed various fears related to their impact on health and the environment. However, the responses revealed a will to gain and improve knowledge, expressed a demand for reliable and accurate information on the risks and safety of GMOs as well as the benefits, and required the labelling of products containing GM ingredients. These observations are of some importance for future management strategies and GM food policies in Poland, which is currently considered the sixth largest economy in the EU and the most important market in Central Europe (Orenstein 2014).

The findings of the present study may be important in setting educational standards in Poland and providing access to substantive, well-balanced information on biotechnological processes and final products. As previously shown, the attitude towards GMOs is a key driver in perceiving its risks and benefits. It can be modified through increasing trust in institutions and researchers (Rodríguez-Entrena and Salazar-Ordóñez 2013), a process which requires the accurate communication of science to mass-media so as to avoid "media hype" (Carsten and Illman 2002; Bubela and Caulfield 2004). Because TV, Internet and the press were indicated by the respondents as primary sources of knowledge for GMOs, ideally, all possible mass media should be involved in communication of science to the general public. This may, however, be challenging as these media are often dominated by sensationalism (Ransohoff and Ransohoff, 2001). Importantly, the surveyed individuals also anticipated information from scientific literature. This can be achieved, inter alia, by increasing the rate of peer-review papers published in the Open Access (OA) mode. Through valuable free, full-text, online resources, OA greatly expands the possibility of instantly and accurately communicating science to the general public and contributes to the avoidance of media misunderstandings and hypes. The present study also indicates an emerging need to raise the role of academicians and school teachers in the public understanding of GMO risks and benefits. Achieving this goal requires a modification of educational programmes to increase biotechnology-related content. It may also involve a need to conduct additional training of school teachers - a group which in the present study was characterized by a low frequency of correct definitions of the term GMO and revealed a high degree of scepticism towards biotechnology. One example of such intersectional training was developed in 2004 by UNESCO (known as "GMO Teaching Kit") and was aimed to empower secondary school teachers to educate and communicate developments and the potential uses and risks of new technological advances, as illustrated by genetic engineering and specifically the use of GMOs (UNESCO 2004). Even though GMOs may still remain controversial to some, every effort should be made to ensure that public opinion is being formed upon evidence-based, well-balanced information rather than hysterical and, to some extent, populist views and debates.

The studied group exhibited general scepticism towards GM foods and expressed various fears related to their use. Farmers, medical workers and school teachers were identified as professions highly reluctant to accept this technology. As stakeholders or educators, these groups are in turn very important in the implementation of GM foods on the market and raising customer acceptance of these products. Therefore there may be great difficulty for the biotechnological industry in overcoming this strong public opposition to their products in Poland.

It should also be highlighted that, in the present study, over $50 \%$ of polled Polish researchers were against the production and distribution of GM foods, contrary to the US where scientists largely consider these products as safe (Pew Research Center 2015). As concluded by the European Commission in 2010 upon evaluation of more than 130 research projects from a period of over 25 years, involving more than 500 independent scientific teams, GM food production cannot be considered more hazardous than conventional plant breeding technologies (European Commission 2010). Recent years have, however, witnessed a number of controversies among which was the highly publicized study by Séralini et al. (2014) reporting that herbicide resistant GM corn and associated herbicide can lead to long-term toxic effects in rats including tumour formations. The study was first retracted by the Editor-in-Chief of Food and Chemical Toxicology, then republished in the journal Environmental Sciences Europe, and eventually divided the scientific environment into critics and those demanding further studies (Loening 2015; Resnik 2015). It also received heavy media coverage which may, at least partially, be responsible for the public fear that GM foods can cause cancer notwithstanding the results of previous shorttem toxicity studies (DeRosier 2015). In the present investigation, cancer development along with allergy were pointed out as the most serious health threat related to GM foods. As recently demonstrated, some scientists hesitate as regards the final conclusion on GMO safety, citing the scarcity and contradictory nature of the scientific evidence published to date (Hilbeck et al. 2015; Krimsky 2015). It is therefore unlikely that the general public will develop an unequivocal opinion under their influence.

However, it is worth noting that the medical and pharmaceutical use of GMOs does not cause such controversies and a 
relatively high proportion of individuals enrolled in the present study perceived potential benefits in adopting GMOs in drugs and vaccine production or lifesaving medical procedures. These differences in public perception of GM foods and medicines may potentially arise from ethical reasons, more obvious benefits and differences in production - production of GM foods includes the deliberate release of a GMO to the environment whereas implementation of GMOs for medical use does not. As shown in a Malaysian study, GM insulin was perceived as having more benefits and was more decidedly supported by the general public than GM soybean (Amin et al. 2013).

The present study also demonstrated that the vast majority of Poles demand that food products containing GM ingredients are labelled. In the EU due to the precautionary principle, all products that contain at least $0.9 \%$ of GM ingredients should be labelled as containing GMOs or GM ingredients according to European Directive 2001/18 and Regulation 1829/2003. Labelling of GMO products undoubtedly assists consumers in making informed purchase decisions, supports customer autonomy (Vecchione et al. 2015) and has been mandatory so far in 64 countries. In the US, despite the majority of the public favouring a labelling policy (Hallman et al. 2013), it is mostly unimplemented and widely criticised due to the costs it may generate and fears that it may be constructed as a reason for caution. It is often suggested that most pro-label individuals would avoid buying GM food (Kling 2014) but this is not supported by our results in which a high proportion of those demanding labelling approved the production and distribution of GM products in Poland. Some others have suggested that consumers aiming to avoid GM foods already have plenty of choices, the purchasing of premium-priced "organic food products" being a major one. Apart from the fact that these products cannot be afforded by a relatively high proportion of customers (Kling 2014), it was recently reported that "organic foods" are often chosen based on a false perception of comparative product safety, nutrition and pro-health attributes (Academics Reviews Report 2014). Consumers have the right to be informed of the origin of products being distributed on the market and it could even be hypothesized that labelling GM products may in fact play a role in increasing the general acceptance of it in the long-term if this were accompanied by focused consumer education (AMA 2012). This issue would, however, require further studies. Importantly in the present study, a significant number of respondents also demanded detailed information on GM products. Although it was not specified what details were expected, it is likely that information on the type of genetic modification applied to obtain a product's ingredients (e.g. herbicide-resistant or Bt toxin) may be anticipated. Such labelling may additionally help customers in understanding the process of production and the variety of genetic modification used by the biotechnological industry. It is also plausible that some customers may accept some types of GMObased technologies in the food industry while they reject others.
Although some European nations were interested in the establishment of a common label within the EU for certified GMfree products (Tsourgiannis et al. 2011), it was suggested that such a 'GM-free' label could bring about a negative impact perception of GM food products by implicating indirectly that they are the ones to be avoided (Maghari and Ardekani 2011).

The limitations of the present study should be stressed. Firstly, the research aimed to reach as many individuals as possible and their total number exceeded 1000, but over $75 \%$ of the surveyed group was restricted to students, school pupils, medical workers, researchers/academicians, school teachers and farmers. Despite the fact that this enabled a comparison between groups possibly involved in shaping the perception of GMOs and GM foods by the general public, it is unclear to what extent the surveyed group represents the general Polish population which currently exceeds 38.5 million. Moreover, the final sample size of some groups (e.g. farmers; $n=40$ ) was relatively low and even though their sceptical attitude towards any use of GMOs was expressed, a more farmer-targeted study may be required to fully elucidate how negative the perception of GMOs in fact is. Finally, the data were partially obtained using an online questionnaire which does not fully exclude the possibility of the surveyed to compare his/her information with that circulating in the Internet (e.g. as regards a question what "GMO" stands for).

In summary, the present study represents the most comprehensive and recent research on attitudes toward GMOs and particularly GM foods in a Central-European country. As demonstrated, Polish society links GMOs mostly with food production, disapproves of GM foods and demands their detailed labelling. The level of concern associated with the health and environmental safety of GM foods was relatively high within the polled group. Greatest scepticism was revealed by groups potentially involved in the application of GM products (farmers and medical workers) and in education (school teachers). Importantly, the respondents demanded the provision of substantive information on GMOs, expressed a will to improve their knowledge of them and recognised the significant need for teachers, academicians and scientific literature to participate in promoting and conveying it. Altogether, the results of this study underline feelings of aversion towards GMOs in Poland. They also highlight the urgent need to implement evidence-based educational programmes in this country to raise public understanding of the current possibilities and limitations of GMOs.

Open Access This article is distributed under the terms of the Creative Commons Attribution 4.0 International License (http:// creativecommons.org/licenses/by/4.0/), which permits unrestricted use, distribution, and reproduction in any medium, provided you give appropriate credit to the original author(s) and the source, provide a link to the Creative Commons license, and indicate if changes were made. 


\section{References}

AbuQamar, S., Alshannag, Q., Sartawi, A., \& Iratni, R. (2015). Educational awareness of biotechnology issues among undergraduate students at the United Arab Emirates university. Biochemistry and Molecular Biology, 43, 283-293.

Academics Review Report. (2014) Why consumers pay more for organic foods? Fear sells and marketers know it. Academics Review Report http://academicsreview.org/wp-content/ uploads/2014/04/AR_Organic-Marketing-Report_Print.pdf. Accessed 18 December 2015

Aerni, P. (2013). Resistance to agricultural biotechnology: the importance of distinguishing between weak and strong public attitudes. Biotechnology Journal, 8, 1129-1132.

Alphey, L. (2014). Genetic control of mosquitoes. Annual Review of Entomology, 59, 205-224.

AMA. (2012) Reference Committee E Report. In: Business of the American Medical Association House of Delegates Annual Meeting, 16-20 Jun 2012. Chicago, IL: American Medical Association.

Amin, L., Jahi, J. M., \& Nor, A. R. (2013). Stakeholders' attitude to genetically modified foods and medicine. ScientificWorldJournal, 2013, 516742.

Boccia, F., \& Sarnacchiaro, P. (2015). Genetically modified foods and consumer perspective. Recent Patents on Food, Nutrition \& Agriculture, 7, 28-34.

Brookes, G., \& Barfoot, P. (2015). Global income and production impacts of using GM crop technology 1996-2013. GM Crops and Food, 6, $13-46$.

Bubela, T. M., \& Caulfield, T. A. (2004). Do the print media "hype" genetic research? A comparison of newspaper stories and peer-reviewed research papers. CMAJ, 170, 1399-1407.

Burke, D. C. (2012). There's a long, long trail a-winding: the complexities of GM foods regulation, a cautionary tale from the UK. GM Crops and Food, 3, 30-39.

Carsten, L. D., \& Illman, D. L. (2002). Perceptions of accuracy in science writing. IEEE Transactions on Professional Communication, 45, $153-156$.

Chen, M. F., \& Li, H. L. (2007). The consumer's attitude toward genetically modified foods in Taiwan. Food Quality and Preference, 18, 662-674.

Comstock, G. (2002). Ethics and genetically modified foods. In M. Ruse \& D. Castle (Eds.), Genetically modified foods: debating biotechnology (pp. 88-107). New York: Prometheus Books.

DeRosier, C., Sulemana, I., James, H. S., Valdivia, C., Folk, W., \& Smith, R. D. (2015). A comparative analysis of media reporting of perceived risks and benefits of genetically modified crops and foods in Kenyan and international newspapers. Public Understanding of Science, 24, 563-581.

EFSA (2010). Special eurobarometer 354. Food-related risks. European commission. http://www.efsa.europa.eu/sites/default/files/assets/ sreporten.pdf. Accessed December 18, 2015.

European Commission. (2010). A Decade of EU-funded GMO Research 2001-2010. EU, Luxemburg, 2010.

European Directive 2001/18/EC of the European Parliament and of the Council of 12 March 2001 on the deliberate release into the environment of genetically modified organisms and repealing Council Directive 90/220/EEC - Commission Declaration

European Directive 2015/412 of the European Parliament and of the Council of 11 March 2015 amending Directive 2001/18/EC as regards the possibility for the Member States to restrict or prohibit the cultivation of genetically modified organisms (GMOs) in their territory.

European Regulation No 1829/2003 of the European Parliament and of the Council of 22 September 2003 on genetically modified food and feed.

Fedoroff, N. (2015). Food in a future of 10 billion. Agriculture \& Food Security, 4, 11.

Hallman, W.K., Cuite, C.L., Morin, X K. (2013) Public perceptions of labeling genetically modified foods. Working Paper 2013-01. Rutgers School of Environmental and Biological Sciences. http:// humeco.rutgers.edu/documents pdf/news/GMlabelingperceptions. pdf. Accessed December 18, 2015.

Hilbeck, A., Binimelis, R., Defarge, N., Steinbrecher, R., Székács, A., Wickson, F., et al. (2015). No scientific consensus on GMO safety. Environmental Sciences Europe, 27, 4.

Jefferson, A., Cadet, V. E., \& Hielscher, A. (2015). The mechanisms of genetically modified vaccinia viruses for the treatment of cancer. Critical Reviews in Oncology/Hematology. doi:10.1016/j. critrevonc.2015.04.001.

Kling, J. (2014). Labeling for better or worse. Nature Biotechnology, 32, $1180-1183$.

Krimsky, S. (2015). An illusory consensus behind GMO health assessment. Science, Technology \& Human Values. doi:10.1177/ 0162243915598381.

Kuntz, M. (2014). The GMO case in France: politics, lawlessness and postmodernism. GM Crops and Food, 5, 163-169.

Loening, U. E. (2015). A challenge to scientific integrity: a critique of the critics of the GMO rat study conducted by Gilles-Eric Séralini et al. Environmental Sciences Europe, $27,13$.

Lucht, J. M. (2015) Public acceptance of plant biotechnology and GM crops.Viruses, 7, 4254-4281.

Maghari, B. M., \& Ardekani, A. M. (2011). Genetically modified foods and social concerns. Avicenna Journal of Medical Biotechnology, 3, 109-117.

Marinotti, O., Jasinskiene, N., Fazekas, A., Scaife, S., Fu, G., Mattingly, S. T., et al. (2013). Development of a population suppression strain of the human malaria vector mosquito, anopheles stephensi. Malaria Journal, 12, 142.

Marris, C. (2001). Public views on GMOs: deconstructing the myths. Stakeholders in the GMO debate often describe public opinion as irrational. But do they really understand the public? EMBO Reports, $2,545-548$.

McHughen, A. (2013). GM crops and foods: what do consumers want to know? GM Crops and Food, 4, 172-182.

Moses, V. (2012). GM in the media. GM Crops and Food, 5, 81-86.

Orenstein, M.A. (2014) Six markets to watch: Poland. Foreign Affairs. https://www.foreignaffairs.com/articles/poland/201312-06/six-markets-watch-poland. Accessed 18 December 2015.

Paarlberg, R. (2014). A dubious success: the NGO campaign against GMOs. GM Crops and Food, 5, 223-228.

Panteli, J. T., Forkus, B. A., Van Dessel, N., \& Forbes, N. S. (2015). Genetically modified bacteria as a tool to detect microscopic solid tumor masses with triggered release of a recombinant biomarker. Integrative Biology, 7, 423-434.

Papatryfon, I., Zika, E., Wolf, O., Gómez-Barbero, M., Stein, A.J., Bock, A.K. (2008) Consequences, Opportunities and Challenges of Modern Biotechnology for Europe - The Analysis Report. European Communities, EUR 23413 EN 2007.

Pew Research Center (2015) Public and scientists views on science and society. http://www.pewinternet.org/files/2015/01/PI 
ScienceandSociety_Report_012915.pdf. Accessed 18 December 2015.

Ransohoff, D. F., \& Ransohoff, R. M. (2001). Sensationalism in the media: when scientists and journalists may be complicit collaborators. Effective Clinical Practice, 4, 185-188.

Resnik, D. B. (2015). Retracting inconclusive research: lessons from the Séralini GM maize feeding study. Journal of Agricultural and Environmental Ethics, 28, 621-623.

Rodríguez-Entrena, M., \& Salazar-Ordóñez, M. (2013). Influence of scientific-technical literacy on consumers' behavioural intentions regarding new food. Appetite, 60, 193-202.

Rylott, E. L., Johnston, E. J., \& Bruce, N. C. (2015). Harnessing microbial gene pools to remediate persistent organic pollutants using genetically modified plants-a viable technology? Journal of Experimental Botany, 66, 6519-6533.

Séralini, G. E., Clair, E., Mesnage, R., Gress, S., Defarge, N., Malatesta, M., et al. (2014). Republished study: long term toxicity of a roundup herbicide and a roundup-tolerant genetically modified maize. Environmental Sciences Europe, 26, 14.

Sorgo, A., \& Ambrožič-Dolinšek, J. (2010). Knowlege of, attitudes toward, and acceptance of genetically modified organisms among prospective teachers of biology, home economics, and grade school in Slovenia. Biochemistry and Molecular Biology Education, 38, 141-150.

Sturgis, P., Cooper, H., \& Fife-Schaw, C. (2005). Attitudes to biotechnology: estimating the opinions of a better-informed public. New Genetics and Society, 24, 31-56.

Tsourgiannis, L., Karasavvoglou, A., \& Florou, G. (2011). Consumers' attitudes towards GM free products in a European region. The case of the Prefecture of Drama-Kavala-Xanthi in Greece. Appetite, 57, $448-458$.

Twardowski, T. (2008). Societal attitudes regarding GM food: the case of Poland within the European Union. Environmental Biosafety Research, 7, 181-184.

UNESCO (2004) GMO Teaching Kit. http://portal.unesco.org/education/ en/file_download.php/3d503b8b5b70152f9d29d2ab 066a4936GMO+Flyer+1.pdf. Accessed 18 December 2015.

Vecchione, M., Feldman, C., \& Wunderlich, S. (2015). Consumer knowledge and attitudes about genetically modified food products and labelling policy. International Journal of Food Sciences and Nutrition, 66, 329-335.
Verdurme, A., \& Viaene, J. (2003). Consumer beliefs and attitude towards genetically modified food: basis for segmentation and implications for communication. Agribusiness, 19, 91-113.

Walsh, G. (2005). Therapeutic insulins and their large-scale manufacture. Applied Microbiology and Biotechnology, 67, 151-159.

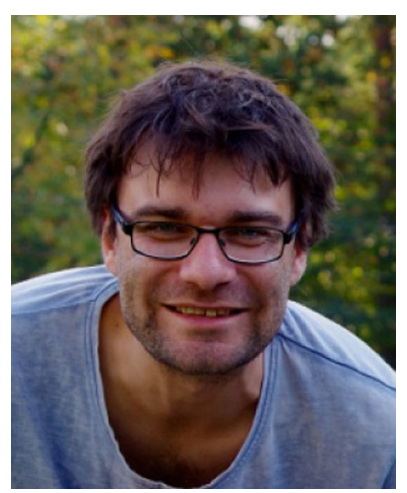

Piotr Rzymski holds a $\mathrm{PhD}$ from Poznan University of Medical Sciences and works both as a researcher and lecturer. His current scientific interests include interdisciplinary studies on environment-human health interactions, ecotoxicology, food quality, functional foods and nutrition.

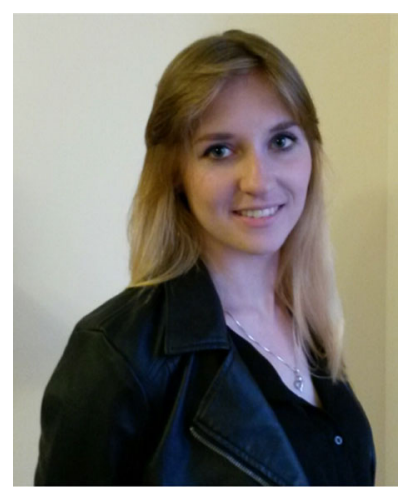

Aleksandra Królczyk is a master's degree student at Poznan University of Medical Sciences, Poland. Her scientific interests include food quality, nutrition, dietary supplements and consumers behaviour. 